\section{Chemical constituents and leishmanicidal activity from leaves of Kielmeyera variabilis}

\section{Betania B. Cota, ${ }^{* 1}$ Ezequias P. Siqueira, ${ }^{1}$ Djalma M. de Oliveira, ${ }^{3}$ Tânia M. A. Alves, ${ }^{1}$ Marcos E. G. Sobral, ${ }^{4}$ Ana Rabello, ${ }^{2}$ Carlos L. Zani $^{1}$}

\author{
${ }^{1}$ Laboratório de Química de Produtos Naturais, Centro de Pesquisas René Rachou, \\ Fiocruz, Minas Gerais, Brazil, \\ ${ }^{2}$ Laboratório de Pesquisas Clínicas do CPqRR-Fiocruz, Minas Gerais; Brazil, \\ ${ }^{3}$ Departamento de Química e Exatas, Universidade Estadual do Sudoeste da Bahia, \\ Campus Jequié, Brazil, \\ ${ }^{4}$ Departamento de Ciências Naturais, Universidade Federal de São João Del-Rei, Minas \\ Gerais, Brazil.
}

\begin{abstract}
Many phenolic compounds such as xanthones, quinones and coumarins have been isolated from Kielmeyera species; however the presence of flavonoids have been showed in other genera in the Calophylleae tribe as Caraipa, Mesua and Calophyllum. Six known glycosidic flavonoids: quercetin 3- $\beta$-O-galactopyranoside (1), quercetin 3- $\beta$ - $O$-glucopyranoside (2), quercetin 3- $O$ - $\alpha$-rhamnoside (3), luteolin 6-C- $\beta$-glucopyranoside (4), isovitexin (5), kaempferol 3-O- $\alpha$-rhamnoside (6) and one triterpene, lupenone (7) were isolated, for the first time, from organic crude extract of Kielmeyera variabilis Mart. \& Zucc., Calophyllaceae, leaves. The crude organic extract from $K$. variabilis leaves exhibited $95 \%$ of leishmanidal activity at $20 \mu \mathrm{g} / \mathrm{mL}$ on amastigote-like form of Leishmania (Leishmania) amazonensis in vitro model and only compound 3 showed $40-45 \%$ of growth inhibition at concentration ranging from 0.78 to $20 \mu \mathrm{g} / \mathrm{mL}$. In addition, quercetin 3- $O$ - $\alpha$-rhamnoside (quercitrin) was found to be the major metabolite. Our results and previous reports suggest that synergistic effects of flavonoid glycosides are the cause of significant leishmanidal activity of the crude organic extract from $K$. variabilis leaves.
\end{abstract}

Revista Brasileira de Farmacognosia Brazilian Journal of Pharmacognosy 22(6): 1253-1258, Nov./Dec. 2012

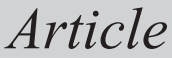

Received 16 Mar 2012

Accepted 17 May 2012

Available online 16 Aug 2012

ISSN 0102-695X http://dx.doi.org/10.1590/S0102695X2012005000095

\section{Introduction}

Kielmeyera variabilis Mart. \& Zucc., Calophyllaceae, is a shrub or tree that reaches up to $6 \mathrm{~m}$ in height and is endemic to the Cerrado (Bittrich, 2010), the savanna-like vegetation of Central-Brazil. It is popularly known as "pau-santo", "rosa-do-campo" or "folha-santa". Methanol extract obtained from $K$. variabilis stems showed molluscicidal activity against Biomphalaria glabrata (12.5 ppm) (Pinheiro et al., 2003a) and activity against Staphylococcus aureus $(3.0 \mu \mathrm{g} / \mathrm{mL})$ and Bacillus subtilis $(1.95 \mu \mathrm{g} / \mathrm{mL})$. A phytochemical study of this species led to the isolation of three xanthones (assiguxanthone-B, kielcorin and 1,3,5,6-tetrahydroxy-2-prenylxanthone) and an organic acid (2,5-dihydroxy benzoic acid), being assiguxanthone-B active against $B$. subtilis $(25 \mu \mathrm{g} / \mathrm{mL})$ (Pinheiro et al., 2003b).

The occurrence of coumarins as phenylcoumarins (Gramacho et al., 1999), prenylated 4- $n$-propylcoumarins (Cruz et al., 1998a,b; Scio et al., 2003) and xanthones (Garcia Cortez et al., 1998, 2002) are frequently reported as isolated compounds from Kielmeyera genus. An osajaxanthone, isolated from a stem extract of Kielmeyera coriaceae showed protection against infection by cercariae of Schistosoma mansoni (Lopes et al., 1977) and other ones have exhibited antifungal activity against the pathogenic plant fungi Cladosporium cucumerinum and Candida albicans (Garcia Cortez et al., 1998). Extracts of leaves from $K$. coriacea have demonstrated anxiolytic activity after oral treatment with $120 \mathrm{mg} / \mathrm{kg}$ body weight per day for thirty days (Audi et al., 2002). Ethanolic extract from stem of $K$. coriacea at a dose of $60 \mathrm{mg} / \mathrm{kg}$ body weight and its dichloromethane semi-pure fraction at dose of 6 $\mathrm{mg} / \mathrm{kg}$ body weight showed similar antidepressant-like effects after 45 days of oral treatment in Male Wistar rats (Martins et al., 2004, 2006). Hexane and dichloromethane extracts from different parts of this species have anticancer activity against SF-295 (brain); HCT-8 (human colon carcinoma); MDA-MB-435 (melanome) and HL-60 (leukemia) with IC50 values ranging from 3.0 to 34.9 $\mu \mathrm{g} / \mathrm{mL}$ (Mesquita et al., 2009). Recently, Sobral et al. (2009) demonstrated antibacterial activity against Micrococcus luteus (CIM $7.8 \mu \mathrm{g} / \mathrm{mL}$ ), Bacillus subitilis 
(CIM $15.6 \mu \mathrm{g} / \mathrm{mL}$ ), Staphylococcus aureus (CIM 31.2 $\mu \mathrm{g} / \mathrm{mL}$ ) and Streptococcus mutans (CIM $31.2 \mu \mathrm{g} / \mathrm{mL}$ ) of the dichloromethane extract from trunk of Kielmeyera cuspidata.

In this work we describe for the first time the isolation of one triterpene and the occurrence of flavonoids, including $O$-flavonoids and $C$-flavonoids, from leaves extract of $K$. variabilis. In addition, we suggested that quercetin 3-O- $\alpha$-rhamnoside is among the leishmanicidal compounds from crude extract.

\section{Materials and Methods}

\section{Plant material}

Leaves of Kielmeyera variabilis Mart. \& Zucc., Calophyllaceae, were collected in Brumadinho, Minas Gerais, Brazil. A voucher specimen was identified and deposited by Dr. Marcos E. G. Sobral in the Herbarium BHCB, at Universidade Federal de Minas Gerais, Instituto de Ciências Biológicas (Stehmann, number 2646) in Belo Horizonte-MG.

\section{General procedures}

The solvents were removed using a SpeedVac ${ }^{\circledR}$ vacuum centrifuge (ThermoSavant SPD SC250, Holbrook, NY, USA). Thin-layer chromatographic (TLC) analyses were conducted on pre-coated commercial silica gel G-60/F ${ }_{254}$ (0.25 mm, Merck, Darmstadt, Germany) plates. They were eluted in a pre-saturated chamber using solvents mixtures in different proportions of: a) chloroform:methanol:water $(65: 50: 5)$; b) hexane:ethyl acetate $(70: 30)$ or c) ethyl acetate:methanol:formic acid:glacial acetic acid:water (100:11:11:26). The spots were visualized under visible, UV light at $254 \mathrm{~nm}$ and $360 \mathrm{~nm}$, and after spraying the plate with mixture $(1: 1)$ of ethanolic solutions of vanillin (1\%) and sulfuric acid (10\%). Medium-pressure liquid chromatography (MPLC) was performed using an LC8 pump (Shimadzu, Kyoto, Japan), Büchi columns n ${ }^{\circ} 19676$ and $\mathrm{n}^{\circ} 19674$ for reverse (RP-18, 25-40 mesh) and normal (silica gel 60, 25-40 mesh) phases, respectively, at flow rates of $20 \mathrm{~mL} / \mathrm{min}$ and detection at $\lambda 220 \mathrm{~nm}$ and $254 \mathrm{~nm}$. Semi-preparative purifications were performed using Shim-pack ${ }^{\circledR}$ C18 column $\left(5 \mu \mathrm{m}, 20 \times 250 \mathrm{~mm}\right.$, i.d.), mixtures of $\mathrm{MeOH}: \mathrm{H}_{2} \mathrm{O}$ as eluents, at flow rates of $10 \mathrm{~mL} / \mathrm{min}$ and detection at $\lambda 220$ and $254 \mathrm{~nm}$ using a Shimadzu chromatographic system (Shimadzu, Kyoto, Japan) equipped with an LC6AD pump and UV-visible dual-wavelength detector (SPD10A). Analytical RP-HPLC analyses were developed in a HPLC system (Shimadzu, Kyoto, Japan) equipped with a LC6AD pump and a SPD M-10A VP Diode Array Detector. Analyses were carried out by Shim-pack ${ }^{\circledR}$ C18 column $(5 \mu \mathrm{m}, 4.6 \times 250 \mathrm{~mm}$ i.d.) eluted with gradient of
$\mathrm{MeOH} / \mathrm{H}_{2} \mathrm{O}$ from $10 \%$ to $100 \%$ of $\mathrm{MeOH}$ at a flow rate of $1 \mathrm{~mL} / \mathrm{min}$. Gel Permeation Chromatography (GPC) was carried out using glass columns filled with Sephadex LH$20^{\mathrm{TM}}$ (GE Healthcare, U.S.A.) gel and $\mathrm{MeOH}$ as mobile phase. NMR (nuclear magnetic resonance) spectra were obtained using a Brucker DRX 400 spectrometer at 400 MHz with the pulse programs provided by the manufacturer. The substances were dissolved in perdeuterated solvents containing $0.1 \%$ tetramethylsilane as the internal chemical shift standard. UV spectra $(200-500 \mathrm{~nm})$ were obtained by Shimadzu SPDM-84 10A VP Diode Array Detector from HPLC system (Shimadzu, Kyoto, Japan). Electrospray ionization mass spectrometry (ESI-MS) were performed using a Bruke maXis ETD (Bruker, DE). Solutions of the compounds at $200 \mu \mathrm{g} / \mathrm{mL}$ in $\mathrm{ACN}: \mathrm{H}_{2} \mathrm{O}$ (1:1) were infused at $3 \mu \mathrm{L} / \mathrm{min}$ with $0.1 \%$ formic acid in the negative mass spectra acquired over a range between $\mathrm{m} / \mathrm{z}$ 50-1500 daltons. The instrument was operated under the following conditions: end plate offset, $-500 \mathrm{~V}$; capillary voltage, 4500 $\mathrm{V}$; nebulizer pressure, 0.4 bar; dry gas (nitrogen) flow rate, $4.0 \mathrm{~L} / \mathrm{min}$; dry temperature, $180^{\circ} \mathrm{C}$; ISCID energy, $0-20$ $\mathrm{eV}$; hexapole RF, $600 \mathrm{Vpp}$; collision energy, $0-30 \mathrm{eV}$; collision RF, $600 \mathrm{Vpp}$; transfer time, 30-100 $\mu$ s.

\section{Extraction and isolation}

Leaves $(62 \mathrm{~g})$ of $K$. variabilis were extracted with a dichloromethane and $\mathrm{MeOH}$ mixture $(1: 1)$ at room temperature. The solution was concentrated under vacuum in a rotary evaporator at temperatures below $45^{\circ} \mathrm{C}$, and the residual solvent was removed in a vacuum centrifuge at $40{ }^{\circ} \mathrm{C}$. Organic crude extract $(3 \mathrm{~g})$ was suspended in $\mathrm{MeOH}: \mathrm{H}_{2} \mathrm{O}(1: 1)$ and extracted with hexane. This procedure afforded a Hex soluble layer (Hex, $0.6 \mathrm{~g}$ ) and an aqueous soluble layer (Aq, $1.8 \mathrm{~g}$ ) fractions. Solvents from fractions were dried using a vacuum centrifuge. The Aq fraction was subjected to reverse-phase MPLC separation using increasing amounts of $10 \%$ aq. $\mathrm{MeOH}$ to produce 31 fractions. Fractions $15\left(\mathrm{MeOH}: \mathrm{H}_{2} \mathrm{O} ; 1: 1\right)$ and 17 (MeOH: $\mathrm{H}_{2} \mathrm{O}$ 70:30) yielded a mixture of compounds 1 and $\mathbf{2}(15 \mathrm{mg})$ and a pure compound $\mathbf{3}(200 \mathrm{mg})$, respectively. Fraction $13\left(\mathrm{MeOH}: \mathrm{H}_{2} \mathrm{O} ; 1: 1\right)$ was purified on semipreparative, using a gradient of $\mathrm{MeOH}: \mathrm{H}_{2} \mathrm{O}(\mathrm{MeOH}, 10-$ $100 \%$ in $40 \mathrm{~min})$ to obtain $4(3 \mathrm{mg})$. Fraction $14(\mathrm{MeOH}$; $100 \%)(45 \mathrm{mg})$ was purified by GPC to afford $5(7 \mathrm{mg})$. Fraction 18 (MeOH: $\left.\mathrm{H}_{2} \mathrm{O} ; 60: 40\right)(49 \mathrm{mg})$ was submitted to semi-preparative HPLC, using a Shim-pack ${ }^{\circledR} \mathrm{C} 18$ column and eluted with mixtures of $\mathrm{MeOH}: \mathrm{H}_{2} \mathrm{O}(50: 50 \rightarrow 70: 30$ in $30 \mathrm{~min} ; 50: 40 \rightarrow 60: 40$ in $2 \mathrm{~min} ; 60: 40$ in $8 \mathrm{~min}$ ) to obtain 6 (3 mg). The Hex fraction was subjected to a normal MPLC, developed with petroleum ether containing increasing amounts of EtOAc to yield seventeen fractions. Fraction $12(210 \mathrm{mg})$ was purified over silica gel column, eluted with Hex-EtOAc (97:3), and then isolated by GPC to yield $7(110 \mathrm{mg})$. 
Quercetin 3- $\beta$-O-galactopyranoside or hyperoside (1) $\mathrm{UV} \lambda_{\max }^{\mathrm{MeOH}} / \mathrm{nm}: 256,356$; $\mathrm{NMR}{ }^{1} \mathrm{H}\left(400 \mathrm{MHz}, \mathrm{CD}_{3} \mathrm{OD}\right)$ : $\delta \mathrm{H} 7.82\left(1 \mathrm{H}, d, J 2.0 \mathrm{~Hz} \mathrm{H}-2^{\prime}\right), 7.62(1 \mathrm{H}, d d, J 8.6$ and $1.1 \mathrm{~Hz}, \mathrm{H}-6$ ') 6.89 (1H, dd, J 8.6 and $2.0 \mathrm{~Hz}, \mathrm{H}-5$ '), 6.43 (1H, d, J 2.0 Hz, H-8), 6.23 (1H, d, J $2.0 \mathrm{~Hz}, \mathrm{H}-6), 5.26$ (1H, d, J $7.6 \mathrm{~Hz}, \mathrm{H}-1$ '”), 3.86 (1H, m, H-4"), 3.81(1H, $d d, J 9.5$ and $8.0 \mathrm{~Hz}, \mathrm{H}-2 "), 3.65(2 \mathrm{H}, d d, J 11.2$ and 6.0 Hz, H-6"), 3.56 (1H, m, H-3"), 3.49 (1H, $t, J 6.0$ $\mathrm{Hz}, \mathrm{H}-5$ "). NMR ${ }^{13} \mathrm{C}\left(100 \mathrm{MHz}, \mathrm{CD}_{3} \mathrm{OD}\right): \delta \mathrm{C} 179.61$ (C-4) 166.13 (C-7), 163.19 (C-5), 158.92 (C-2), 158.56 (C-9), 150.06 (C-4'), 146.12 (C-3'), 135.66 (C-3), 123.34 (C-1'), 123.16 (C-6'), 117.92 (C-2'), 116.39 (C-5'), 105.66 (C-10), 105.16 (C-1"), 100.07 (C-6), 94.91 (C-8), 77.37 (C-5"), 75.18 (C-3"), 73.25 (C-2”), 70.12(C-4"), 62.10 (C-6"). ESI-MS $\mathrm{m} / \mathrm{z}$ negative mode: 463.0788 [M-H] ${ }^{-}, \mathrm{MS}^{2}$ [300.0216].

Quercetin 3- $\beta$ - $O$-glucopyranoside or isoquercitrin (2) $\mathrm{UV} \lambda_{\max }^{\mathrm{MeOH}} / \mathrm{nm}: 256,356 ; \mathrm{NMR}^{1} \mathrm{H}\left(400 \mathrm{MHz}, \mathrm{CD}_{3} \mathrm{OD}\right)$ : $\delta \mathrm{H} 7.62(1 \mathrm{H}, d d, J 8.6$ and $1.1 \mathrm{~Hz}, \mathrm{H}-6$ ') $7.73(1 \mathrm{H}, d, J$ $2.0 \mathrm{~Hz} \mathrm{H}-2^{\prime}$ ), 6.89 (1H, $d d, J 8.6$ and $1.8 \mathrm{~Hz}, \mathrm{H}-5$ '), 6.43 (1H, d, J 2.0 Hz, H-8), 6.23 (1H, d, J $2.0 \mathrm{~Hz}, \mathrm{H}-6), 5.35$ $(1 \mathrm{H}, d, J 7.2 \mathrm{~Hz}, \mathrm{H}-1$ ") $), 3.72(2 \mathrm{H}, d d, J 12.0$ and 2.2 Hz, H-6"a), 3.58 (m, H-6"b), 3.47 (1H, m, H-2"), 3.43 (1H, m, H-5"), 3.35 (1H, m, H-4"), 3.24 (1H, ddd, J9.0, 5.0 and $2.0 \mathrm{~Hz}, \mathrm{H}-3$ "). NMR ${ }^{13} \mathrm{C}\left(100 \mathrm{MHz}, \mathrm{CD}_{3} \mathrm{OD}\right)$ : ઈC 179.57 (C-4), 166.07 (C-7), 163.19 (C-5), 158.79 (C-2), 158.53 (C-9), 149.97 (C-4'), 146.12 (C-3’), 135.65 (C-3), 123.33 (C-1'), 123.17 (C-6’), 117.76 (C-2'), 116.31 (C-5'), 105.66 (C-10), 104.10 (C-1"), 100.07 (C-6), 94.91 (C-8), 78.63 (C-5”), 78.26 (C-3”), 75.87 (C-2"), 71.41 (C-4"), 62.68 (C-6"). ESI-MS m/z negative mode: 463.0788 [M - H] $]^{-}, \mathrm{MS}^{2}$ [300.0216].

Quercetin 3-O- $\alpha$-rhamnoside or quercitrin (3) UV $\lambda_{\max }^{\mathrm{MeOH}}$ /nm: 256, 350; NMR ${ }^{1} \mathrm{H}\left(400 \mathrm{MHz}, \mathrm{CD}_{3} \mathrm{OD}\right): \delta \mathrm{H} 7.34$ $\left(1 \mathrm{H}, d d, J 8.3\right.$ and $\left.2.0 \mathrm{~Hz}, \mathrm{H}-2^{\prime}\right), 7.30(1 \mathrm{H}, d d, J 8.3$ and $\left.2.0 \mathrm{~Hz}, \mathrm{H}-6^{\prime}\right), 6.93$ (1H, $\left.d, J 8.3 \mathrm{~Hz}, \mathrm{H}-5^{\prime}\right), 6.36$ (1H, $d$, $J$ 2.0, H-8), 6.19 (1H, d, J $2.0 \mathrm{~Hz}, \mathrm{H}-6), 5.34$ (1H, $d, J$ $1.3 \mathrm{~Hz}, \mathrm{H}-1$ "), 4.21 (1H, dd, J 3.0 and 1.5, H-5"), 3.74 ( $1 \mathrm{H}, d d, J 9.4$ and $3.2 \mathrm{~Hz}, \mathrm{H}-3$ ") $), 3.42$ (1H, dq J 9.4 and $6.1 \mathrm{~Hz}, \mathrm{H}-2$ "), 3.32 (1H, dd, J 9.3 and 2.0, 4"), 0.93 (3H, d, J 6.1 Hz, H-6"). NMR ${ }^{13} \mathrm{C}\left(100 \mathrm{MHz}, \mathrm{CD}_{3} \mathrm{OD}\right)$ : אC 179.65 (C-4), 165.95 (C-7), 163.21 (C-5), 159.32 (C-2), 158.54 (C-9), 149.80 (C-4'), 146.41 (C-3'), 136.24 (C-3), 123.00 (C-1'), 122.87 (C-6'), 116.96 (C-2'), 116.38 (C-5'), 105.89 (C-10), 103.55 (C-1'), 99.85 (C-6), 94.74 (C-8), 73.27 (C-4"), 72.14 (C-3"'), 72.03 (C-2”), 71.90 (C-5”), 17.64 (C-6”). ESI-MS m/z negative mode: 447.0885 [M-H] ${ }^{-}, \mathrm{MS}^{2}$ [300.0248].

Luteolin 6-C- $\beta$-D-glucopyranoside or isoorientin (4) $\mathrm{UV} \lambda{ }_{\max }^{\mathrm{MeOH}} / \mathrm{nm}: 269,339 ; \mathrm{NMR}^{1} \mathrm{H}\left(400 \mathrm{MHz}, \mathrm{CD}_{3} \mathrm{OD}\right)$ : $\delta \mathrm{H} 7.39(1 \mathrm{H}, d d, J 8.6$ and $2.3 \mathrm{~Hz}, \mathrm{H}-6$ ') $7.36(1 \mathrm{H}$, $\left.s, \mathrm{H}-2^{\prime}\right), 6.91$ (1H, $d, J 8.6$ and $\left.1.4 \mathrm{~Hz}, \mathrm{H}-5^{\prime}\right), 6.56$
(1H, s, H-3), 6.50 (1H, s, H-8), $4.91(1 \mathrm{H}, d, J 9.8 \mathrm{~Hz}$ H-1"), 4.16 (1H, $t$ like, $J 9.5 \mathrm{~Hz}, \mathrm{H}-2$ "), 3.88 (1H, dd, $J 12.0$ and $2.0 \mathrm{~Hz}, \mathrm{H}-6 "), 3.74$ (1H, dd, $J 12.0$ and 5.2 $\mathrm{Hz}, \mathrm{H}-6 "), 3.50$ (2H, m, H-4"), 3.49 (1H, m, H-3"), 3.47 (1H, m, H-5”). NMR ${ }^{13} \mathrm{C}\left(100 \mathrm{MHz}, \mathrm{CD}_{3} \mathrm{OD}\right)$ :

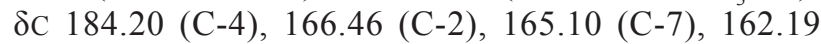
(C-5), 158.89 (C-9), 151.22 (C-4'), 147.22 (C-3'), 123.74 (C-1'), 120.48 (C-6'), 116.96 (C-5'), 114.32 (C-2'), 109.36 (C-6), 105.37 (C-10), 104.10 (C-3), 95.35 (C-8), 82.78 (C-5”), 80.29 (C-3”), 75.47 (C-1”), 72.77 (C-2"), 71.94 (C-4"), 63.01 (C-6"). ESI-MS m/z negative mode: 431.0866 [M-H] ${ }^{-}, \mathrm{MS}^{2}$ [311.0480].

Isovitexin (5) UV $\lambda_{\max }^{\mathrm{MeOH}} / \mathrm{nm}: 270,337$; NMR ${ }^{1} \mathrm{H}(400$ $\left.\mathrm{MHz}, \mathrm{CD}_{3} \mathrm{OD}\right): \delta \mathrm{H} 7.91(1 \mathrm{H}, d d, J 8.8 \mathrm{~Hz}, \mathrm{H}-2$ ' and H-6'), 6.99 (1H, d, J 8.8 Hz, H-3' and H-5'), 6.68 (1H, $s, \mathrm{H}-3), 6.59$ (1H, s, H-8), 4.92 (1H, $d, J 10.0 \mathrm{~Hz}, \mathrm{H}-1$ '”), $4.15(1 \mathrm{H}, m, \mathrm{H}-2$ "), $3.90(1 \mathrm{H}, d d, J 12.0$ and $2.0 \mathrm{~Hz}$, H-6"'b), 3.76 (1H, d, J 12.0 and 7.0 Hz, H-6"'a), 3.47 (2H, $m, \mathrm{H}-3$ " and H-4"), 3.41 (1H, $m, \mathrm{H}-5$ "). NMR ${ }^{13} \mathrm{C}$ (100 MHz, CD $\left.{ }_{3} \mathrm{OD}\right)$ : $\delta \mathrm{C} 184.05$ (C-4), 166.13 (C-2), 165.23 (C-7), 162.91 (C-9), 162.15 (C-4'), 158.77 (C-5), 2x 129.67 (C-2' and C-6'), 123.27 (C-1'), 2x 117.27 (C-3' and C-5'), 109.58 (C-6), 105.27 (C-10), 104.17 (C-3), 95.48 (C-8), 82.78 (C-5”), 80.31 (C-3"), 75.38 (C-1"), 72.65 (C-2”), 71.92 (C-4"), 62.95 (C-6”). ESI-MS $m / z$ negative mode: 431.0910 [M-H] $]^{-} \mathrm{MS}_{2}$ [341.0611], $\mathrm{MS}_{2}[311.0511]$.

Kaempferol 3-O- $\alpha$-rhamnoside (6) UV $\lambda_{\max }^{\mathrm{MeOH}} / \mathrm{nm}: 264$, 344; NMR ${ }^{1} \mathrm{H}\left(400 \mathrm{MHz}, \mathrm{DMSO}-\mathrm{d}_{6}\right): \delta \mathrm{H} 7.75(1 \mathrm{H}, d, J$ $8.8 \mathrm{~Hz}, \mathrm{H}-2^{\prime}$ ' and H-6'), $6.96(1 \mathrm{H}, d, J 8.8 \mathrm{~Hz}, \mathrm{H}-3$ ' and H-5'), 6.38 (1H, d, J 2.0, H-8), 6.27 (1H, d, J 2.0 Hz, H-6), 5.51 (1H, br s, H-1"), $4.26(1 \mathrm{H}, d d, J 3.0$ and 1.2 Hz, H-2"), 3.71 (1H, dd, J 9.0 and $3.2 \mathrm{~Hz}, \mathrm{H}-3$ "), 3.36 (1H, m, Hz, 4"), 3.30 (1H, m, H-5"), 0.96 (3H, d, J 6.0 $\mathrm{Hz}, \mathrm{H}-6 ")$. NMR ${ }^{13} \mathrm{C}\left(100 \mathrm{MHz}, \mathrm{CD}_{3} \mathrm{OD}\right): \delta \mathrm{C} 179.00$ (C-4), 164.38 (C-7), 162.10 (C-5), 160.22 (C-4), 157.71 (C-2), 157.15 (C-9), 134.88 (C-3), 130.75 (C-2' and C-6'), 121.42 (C-1'), 2x 115.82 (C-3' and C-5'), 105.16 (C-10), 101.72 (C-1'), 99.29 (C-6), 94.10 (C-8), 72.50 (C-4"), 71.66 (C-3"), 70.52 (C-2”), 70.47 (C-5”), 17.44 (C-6"). ESI-MS $m / z$ negative mode: 431.0873 [M-H]', $\mathrm{MS}^{2}, \mathrm{MS}^{2}[285.0331]$.

Lupenone (7) NMR ${ }^{1} \mathrm{H}\left(400 \mathrm{MHz}, \mathrm{CDCl}_{3}\right)$ : $\delta \mathrm{H} 4.69$ (br s, H-29), 4.57 (br s, H-29), 2.42 ( $m, \mathrm{H}-2), 2.38$ (m, $\mathrm{H}-19), 1.69,1.89$ ( $m, \mathrm{H}-1), 1.68$ (H-30 and H-13), 1.46 ( $m, \mathrm{H}-6), 1.42$ ( $m, \mathrm{H}-7), 1.38,1.48$ ( $m, \mathrm{H}-16), 1.37(m$, H-9 and H-18), 1.32, 1.91 ( $m, \mathrm{H}-21), 1.31$ ( $m, \mathrm{H}-5)$, $1.26,1.40$ ( $m, \mathrm{H}-11), 1.19,1.38$ ( $m, \mathrm{H}-22), 1.07$ ( $s$, $\mathrm{H}-25$ and $\mathrm{H}-23$ and $\mathrm{H}-26), 1.07,1.69$ ( $m, \mathrm{H}-12), 1.03$, 1.69 ( $m, \mathrm{H}-15), 1.01$ ( $s, 3 \mathrm{H}, \mathrm{H}-24), 0.95$ ( $s, 3 \mathrm{H}, \mathrm{H}-27)$, $0.93(s, 3 \mathrm{H}, \mathrm{H}-25), 0.79(s, 3 \mathrm{H}, \mathrm{H}-28) . \mathrm{NMR}{ }^{13} \mathrm{C}(100$ $\mathrm{MHz}_{\mathrm{CDCl}}$ ): $\delta \mathrm{C} 218.31(\mathrm{C}-3), 150.91$ (C-20), 109.41 
(C-29), 54.94 (C-5), 49.81 (C-9), 48.26 (C-18), 47.98 (C-19), 47.36 (C-4), 43.01 (C-14), 42.91 (C-17), 40.80 (C-),39.99 (C-22), 39.63 (C-1), 38.19 (C-13), 36.90 (C-10), 35.54 (C-16), 34.18 (C-2), 33.58 (C-7), 29.73 (C-21), 27.45 (C-15), 26.66 (C-23), 25.17 (C-12), 21.49 (C-11), 21.05 (C-24), 19.70 (C-6), 19.33 (C-30), 18.03 (C-28), 15.99 (C-25), 15.80 (C-26), 14.50 (C-27).

Assays with Leishmania (Leishmania) amazonensis

Leishmanicidal activity of the isolated compounds was determined against amastigote-like forms as previously described by Cota et al. (2008a). Briefly: promastigotes of Leishmania (L.) amazonensis (strain IFLA/BR/196/PH-8) were obtained from lesions of infected hamsters. The parasites were grown at 26 ${ }^{\circ} \mathrm{C}$ in $\mathrm{pH}$ 7.2 Schneider's medium, and then stimulated to differentiate into the amastigote forms by rising the temperature $\left(32^{\circ} \mathrm{C}\right)$, and lowering the $\mathrm{pH}(6.0)$ of the Schneider's medium. After seven days under these conditions, $90 \%$ of the promastigotes were transformed into amastigote-like forms, verified by means of microscope, and then used in the bioassays. Amastigote density was adjusted to $1 \times 10^{8}$ parasites per $\mathrm{mL}$, and 90 $\mu \mathrm{L}$ added to each well of 96 -well plates. Solutions at $200 \mu \mathrm{g} / \mathrm{mL}$ in DMSO (1\% in water) were performed for each fraction or compound and then ten microliters of the solution were added to each well of 96-well plates. The plates were incubated at $32{ }^{\circ} \mathrm{C}$ for $72 \mathrm{~h}$, and then the cells viability was determined using the MTT (methyl thiazolyl tetrazolium) assay (Teixeira et al., 2002). The results were expressed as percent inhibition in relation to the controls without drug. Amphotericin B at $0.2 \mu \mathrm{g} / \mathrm{mL}$ (Fungison ${ }^{\circledR}$ Bristol-Myers Squibb B, Brazil) was used as a positive drug control. All assays were performed in triplicate.

\section{Results and Discussion}

The structures of isolated compounds were identified by a combination of spectroscopic methods (MS, 1 D NMR and 2D NMR) and comparisons with the literature data as a mixture of quercetin $3-\beta-O-$ galactopyranoside or hyperoside (1) and quercetin 3- $\beta-O$ glucopyranoside or isoquercitrin (1:1) (2) (Almeida et al., 1998; Costa et al., 2007; Ohguchi et al., 2010), quercetin 3-O- $\alpha$-rhamnoside or quercitrin (3) (Zhong et al., 1997), luteolin 6-C- $\beta$-glucopyranoside or orientin (4) (Li et al., 2009), apigenin-6- $C$-glucoside or isovitexin (5) (Leong et al., 2010), kaempferol 3-O- $\alpha$-rhamnoside (6) (Fossen et al., 1999) and lupenone (7) (Prachayasittikul et al., 2010), respectively. Characterization of the sugar moieties from the mixture of quercetin 3- $\beta$-galactopyranoside (1) and quercetin 3- $\beta$-glucopyranoside (2) was performed according Cota et al. 2008b.

In this work, we isolated six flavonoids (1-6) and one lupane triterpene (7) for the first time from Kielmeyera variabilis Mart. \& Zucc., Calophyllaceae. Triterpenes with different carbon skeletons that include lupeol, friedelin, $\beta$-amyrin and the sterol $\beta$-sitosterol, were found in $K$. rugosa Choisy (Nogueira et al., 2008), K. lathrophyton Saddi (Cruz et al., 2001), K. candidissima (Ferreira et al., 1972), K. speciosa A. St.-Hil. (Gottlieb et al., 1970) and K. rugosa Choisy (Nogueira et al., 2008), respectively. Indeed, GarciaCortez et al. (1998) obtained a mixture of 27-O-cis and trans-p-coumaroylcylicodiscic acid, lupeol derivated triterpenes from a dichloromethane extract of $K$. coriaceae leaves. Our chemical study on the aqueoussoluble fraction resulted in the isolation of glycosilated flavonoids, where two of them are $C$-flavonoids (4-5). The major compound from Aq soluble fraction in $K$. variabilis was found to be quercitrin (3) what suggests that this species is a good source of this flavonoid.

Many phenolic compounds such as xanthones (Pinheiro et al., 2003a; Sobral et al., 2009), quinones (Corrêa et al., 1970) and coumarins (Cruz et al., 1998b) have been isolated from Kielmeyera species. Despite 4-alkyl and 4-phenyl coumarins having been identified as the major constituents of some species that occur mainly<smiles>[R]c1cc(-c2oc3cc(O)c([R2])c(O)c3c(=O)c2[R2])ccc1O</smiles>

$1 \mathrm{R}_{1}=\mathrm{OH} ; \mathrm{R}_{2}=\mathrm{O}-\beta-\mathrm{gal} ; \mathrm{R}_{3}=\mathrm{H}$

$2 \mathrm{R}_{1}=\mathrm{OH} ; \mathrm{R}_{2}=\mathrm{O}-\beta$-glc; $\mathrm{R}_{3}=\mathrm{H}$

$3 \mathrm{R}_{1}=\mathrm{OH} ; \mathrm{R}_{2}=\mathrm{O}-\alpha$-rham; $\mathrm{R}_{3}=\mathrm{H}$

$4 \mathrm{R}_{1}=\mathrm{OH} ; \mathrm{R}_{2}=\mathrm{H} ; \mathrm{R}_{3}=C-\beta$-glc

$5 \mathrm{R}_{1}=\mathrm{R}_{2}=\mathrm{H} ; \mathrm{R}_{3}=C-\beta$-glc

$6 \mathrm{R}_{1}=\mathrm{R}_{3}=\mathrm{H} ; \mathrm{R}_{2}=\mathrm{O}-\alpha$-rham

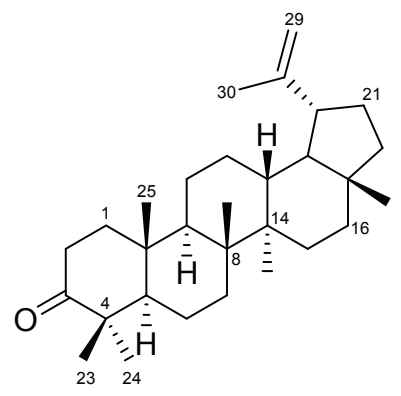

7 
in the cerrado (Gottlieb et al., 1969; Gottlieb \& Stefani, 1970) and restinga (Cruz et al., 2002; Nogueira et al., 2008) and xanthones from species collected in the atlantic forest (Garcia-Cortez et al.,1998; Pinheiro et al., 2003a), $K$. variabilis did not demonstrate the same pattern as observed by previous studies. The presence of flavonoids in this species is in agreement with previous reports from other genera in the Calophylleae tribe as Caraipa (Silveira et al., 2010), Mesua (Banerji \& Chowdhury, 1993) and Calophyllum (Cechinel et al., 2009). It is known that temperature and UV radiation can up-regulate key genes (Christie \& Jenkins, 1996) that give plants the ability to offset the excessive absorption of UV radiation by accumulating UV-filtering secondary metabolites such as flavonoids (Cuadra et al., 1997). The chemotaxonomic applicability of phenolic compounds from Kielmeyera genus as markers needs to be properly evaluated, considering more members of the genus, their distribution and environmental influence.

The crude organic extract from $K$. variabilis leaves exhibited $95 \%$ of leishmanidal activity at $20 \mu \mathrm{g} / \mathrm{mL}$ on amastigote-like form of Leishmania amazonensis. From isolated compounds 1-7, only quercitrin was able to inhibit the growth amastigote-like form of $L$. amazonensis, but it was not dose-dependent in this assay $(0.78-20 \mu \mathrm{g} / \mathrm{mL}, 40-$ $45 \%)$. The major compound from Aq soluble fraction in $K$. variabilis was found to be quercitrin what suggests that this species is a good source of this flavonoid. The potent antileishmanial activity of quercetrin was demonstrated by in vitro bioguided fractionation of Kalanchoe pinnata (Muzitano et al., 2006a). In addition, previous study showed that oral administration of $16 \mathrm{mg} / \mathrm{kg}$ body weight of quercetin $3-O-\alpha$-L-arabinopyranosyl $(1 \rightarrow 2)-\alpha$-Lrhamnopyranoside or quercetrin or quercetin for 30 days in BALB/c mice suppressed parasite burden by $65 \%, 57 \%$, and $76 \%$ in the lesion from infected ear compared with the untreated mice and similar to intraperitoneal pentostam (62\%) (Muzitano et al., 2006b). These biological results and our in vitro studies are good evidence that synergistic effects of flavonoid glycosides are the cause of significant leishmanidal activity of crude organic extract from $K$. variabilis leaves.

\section{Acknowledgment}

The authors thank Fiocruz and Fapemig for financial support. We are also grateful to Daniela Nabak Bueno Maia and Luciana Alves Rodrigues dos Santos Lima for technical assistance.

\section{References}

Almeida AP, Miranda MMFS, Simoni IC, Wigg MD, Lagrota MHC, Costa SS 1998. Flavonol monoglycosides isolated from the antiviral fractions of Persea americana
(Lauraceae) leaf infusion. Phytother Res 12: 562-567.

Audi EA, Otobone F, Martins JV, Cortez DA 2002. Preliminary evaluation of Kielmeyera coriacea leaves extract on the central nervous system. Fitoterapia 73: 517-519.

Banerji R, Chowdhury AR 1993. Mesua ferrea: Chemical constituents and biological. $J$ Chem Soc Pakistan 15: 207-211.

Bittrich V 2010. Clusiaceae in lista de espécies da flora do Brasil. Jardim Botânico do Rio de Janeiro, Rio de Janeiro, Brazil. http://floradobrasil.jbrj.gov.br/2010/ FB000089, Accessed 1 Feb 2011.

Cechinel Filho V, Meyre-Silva C, Niero R 2009. Chemical and pharmacological aspects of the genus Calophyllum. Chem Biodivers 6: 313-327.

Christie JM, Jenkins GI 1996. Distinct UV-B and UV-A/blue light signal transduction pathways induce chalcone synthase gene expression in Arabidopsis cells. Plant Cell 8: 1555-1567.

Corrêa DB, Silva, LGF, Gottlie OR, Gonçalves SJ 1970. Quinone and xanthone constituents of. Kielmeyera rupestris. Phytochemistry 9: 447-451.

Costa DA, Silva DA, Cavalcanti AC, Medeiros MAA, Lima JT, Cavalcante JMS, Silva BA, Agra MF, Souza MFV 2007. Chemical constituents from Bakeridesia pickelii Monteiro (Malvaceae) and the relaxant activity of kaempferol-3-O- $\beta$-D-(6"-E-p-coumaroyl) glucopyranoside on guinea-pig ileum. Quim Nova 30: 901-903.

Cota BB, Rosa LH, Caligiorne RB, Rabello ALT, Alves TMA, Rosa CA, Zani CL 2008a. Altenusin, a biphenyl isolated fromthe endophytic fungus Alternaria sp., inhibits trypanothione reductase from Trypanosoma cruzi. FEMS Microbiol Lett 285: 177-182.

Cota BB, Magalhães A, Pimenta AMC, Siqueira EP, Alves TMA, Zani CL, 2008b. Chemical constituents of Habenaria petalodes Lindl. (Orchidaceae). J Braz Chem Soc 19: 1098-1104.

Cuadra P, Harborne JB, Waterman PG 1997. Increases in surface flavonols and photosynthetic pigments in Gnaphalium luteo-album in response to UV-B radiation. Phytochemistry 45: 1377-1383.

Cruz FG, David JM, Guedes MLS, Chávez JP, Moreira LM 1998a. Coumarins from Kielmeyera reticulata. Phytochemistry 47: 1363-1366.

Cruz FG, David JM, Guedes MLS, Chávez JP, Santos NAS 1998b. Coumarins from Kielmeyera argentea. Phytochemistry 48: 703-706.

Cruz FG, Silva-Neto JT, Guedes MLS 2001. Xanthones and coumarins from Kielmeyera lathrophyton. J Braz Chem Soc 12: 117-122.

Cruz FG, Moreira LM, Santos NAS, Guedes MLS 2002. Additional coumarins from Kielmeyera reticulate. $J$ Braz Chem Soc 13: 704-707.

Ferreira GAL, Gottlieb OR, Mesquita AAL 1972. Xanthones from a Kielmeyera species Phytochemistry 11: 1512- 
1513.

Fossen T, Larsen A, Kiremire BT, Andersen M 1999. Flavonoids from blue flowers of Nymphaèa caerulea. Phytochemistry 51: 1133-1137.

Garcia Cortez DA, Young MCM, Marston A, Wolfender JL, Hostettmann K 1998. Xanthones, triterpenes and a biphenyl from Kielmeyera coriacea. Phytochemistry 47: 1367-1374.

Garcia Cortez DAG, Abreu Filho BA, Nakamura CV, Dias Filho BP, Marston A, Hostettmann K 2002. Antibacterial activity of a biphenyl and xanthones from Kielmeyera coriacea. Pharm Biol 40: 485-489.

Gottlieb OR, Lins Mesquita AA, Martins da Silva E, Teixeira de Melo M 1969. Xanthones of Kielmeyera ferruginea. Phytochemistry 8: 665-666.

Gottlieb OR, Stefani GM 1970. Xanthones from Kielmeyera excelsa. Phytochemistry 9: 453-454.

Gottlieb OR, Mesquita AAL, Oliveira GG, Melo MT 1970. Xanthones from Kielmeyera speciosa. Phytochemistry 9: 2537-2544.

Gramacho RS, Nagem TJ, Oliveira TT, Queiroz MELR, Neves AA, Saddi N 1999. Phenylcoumarins from Kielmeyera elata. Phytochemistry 51: 579-581.

Leong ACN, Kinjo Y, Tako M, Iwasaki H, Oku H, Tamaki $\mathrm{H}$ 2010. Flavonoid glycosides in the shoot system of Okinawa Taumu (Colocasia esculenta S.). Food Chem 119: 630-635.

Li L, Henry GE, Seeram NP 2009. Identification and bioactivities of resveratrol oligomers and flavonoids from Carex folliculata seeds. J Agric Food Chem 57: 7282-7287.

Lopes JLC, Lopes JNC, Gilbert B, Bonini SE 1977. Osajaxanthone from Kielmeyera coriacea. Phytochemistry 16: 1101-1101.

Martins JVC, Otobone FJ, Sela VR, Obici S, Trombelli MA, Cortez DAG, Audi EA 2004. Activity of hydroethanolic extract from Kielmeyera coriacea stems on central nervous system in rats. Acta Sci Health Sci 26: 365-368.

Martins JVC, Otobone FJ, Sela VR, Obici S, Trombelli MA, Cortez DAG, Audi EA 2006. Behavioral effects of Kielmeyera coriacea extract in rats. Indian $J$ Pharmacol 38: 427-428.

Mesquita ML, de Paula JE, Pessoa C, de Moraes MO, Costa-Lotufo LV, Grougnet R, Michel S, Tillequin F, Espindola LS 2009. Cytotoxic activity of Brazilian Cerrado plants used in traditional medicine against cancer cell lines. J Ethnopharmacol 123: 439-445.

Muzitano MF, Cruz EA, Almeida AP, Silva SAG, Kaiser CR, Guette C, Rossi-Bergmann B, Costa SS 2006a. Quercitrin: An antileishmanial flavonoid glycoside from Kalanchoe pinnata. Planta Med 72: 81-83.

Muzitano MF, Tinoco LW, Guette C, Kaiser CR, Rossi-Bergmann B, Costa SS 2006b. Assessment of antileishmanial activity of new and unusual flavonoids from Kalanchoe pinnata. Phytochemistry 67: 2071-2077.

Nogueira PCL, Moacir SA, Larissa MA, Moraes VRS, Ribeiro AS, Bittrich V, Amaral MCE, Ferreira AG, Alcântara GB, Leão KV, Alves PB 2008. Chemical constituents from Kielmeyera rugosa Choisy (Clusiaceae). Biochem Syst Ecol 36: 921-924.

Ohguchi K, Nakajima C, Oyama M, Iinuma M, Itoh T, Akao Y, Nozawa Y, Ito M 2010. Inhibitory effects of flavonoid glycosides isolated from the peel of Japanese Persimmon (Diospyros kaki 'Fuyu') on melanin biosynthesis. Biol Pharm Bull 33: 122-124.

Pinheiro L, Vidotti GJ, Young MCC, Ferreira AG, Cortez, Diogenes AG 2003a. Phytochemical study and evaluation of the molluscicidal activity of Kielmeyera variabilis Mart. (Clusiaceae). Quim Nova 26: 157-160.

Pinheiro L, Nakamura CV, Dias Filho BP, Ferreira AG, Young MCM, Garcia Cortez DA 2003b. Antibacterial xanthones from Kielmeyera variabilis Mart. (Clusiaceae). Mem I Oswaldo Cruz 98: 549-552.

Prachayasittikul S, Saraban P, Cherdtrakulkiat R, Ruchirawat S, Prachayasittikul V 2010. New bioactive triterpenoids and antimalarial activity of Diospyros rubra Lec. Excli J 9: 1-10.

Scio E, Ribeiro A, Alves TMA, Álvaro JR, Young GS, Cordell GA, Zani CL 2003. New bioactive coumarins from Kielmeyera albopunctata. J Nat Prod 66: 634-637.

Silveira CV, Trevisan MTS, Rios JB, Erben G, Haubner R, Pfundstein B, Owen RW 2010. Secondary plant substances in various extracts of the leaves, fruits, stem and bark of Caraipa densifolia Mart. Food Chem Toxicol 48: 1597-1606.

Sobral IS, Souza-Neta LC, Costa GAN, Guedes MLS, Martins D, Cruz FG 2009. Xantonas, triterpenos e atividade antibacteriana do extrato em diclorometano de Kielmeyera cuspidata Saddi, Clusiaceae. Rev Bras Farmacogn 19: 686-689.

Teixeira MCA, Santos RJ, Sampaio RB, Carvalho LP, Santos WLC 2002. A simple and reproducible method to obtain large numbers of axenic amastigotes of different Leishmania species. Parasitol Res 88: 963-968.

Zhong XN, Otsuka H, Ide T, Hirata E, Takushi A, Takeda Y1997. Three flavonol glycosides from leaves of Myrszne seguinii. Phytochemistry 46: 943-946.

\section{*Correspondence}

\section{Betania Barros Cota}

Laboratório de Química de Produtos Naturais, Centro de Pesquisas René Rachou, Fundação Oswaldo Cruz

Av. Augusto de Lima, 1715, 30190-002 Belo Horizonte-MG, Brazil

betania@cpqrr.fiocruz.br

Tel.:+55 3133497845

Fax: +553132953115 